\title{
POTRET GERAKAN AHMADIYAH DI INDONESIA DALAM BUKU PROF. ISKANDAR ZULKARNAIN
}

\author{
Titian Ayu Nawtika ${ }^{1}$, Muhammad Yuslih ${ }^{2}$ \\ 1,2Universitas Islam Negeri Sunan Kalijaga Yogyakarta \\ 1titianayu117@gmail.com \\ 2muhammadyuslih48@gmail.com
}

\begin{abstract}
Abstrak: Muhammadiyah merupalan salah satu organisasi keagamaan yang didirikan oleh seorang tokoh pembaharu bernama Mirza Ghulam Ahmad yang berasal dari India. Ide pembaruan ini muncul dikarenakan pada saat itu keadaan masyarakat India khususnya umat Islam mengalami keterbelakangan dan kemunduran di berbagai bidang seperti agama, politik, ekonomi, sosial. Gerakan ini menekankan aspek-aspek ideologis-eskatologis, dimana gerakan ini meyakinkan bahwa Mirza Ghulam Ahamad mendeklarasikan dirinya sebagai al-Mahdi dan al-Masih yang telah diberi amanah oleh Allah dalam mimpinya tanggung jawab moral untuk memajukan Islam dan bagi umat Islam mempercayai imam al-Mahdi dipandang sebagai "Hakim peng-islah" atau sebagai "Juru Damai". Adapun dalam penelitiannya oleh Prof. Iskandar Zulkarnain menggunakan pendekatan sejarah. Dari hasil penelitian yang dilakukannya bebrapa ajaran Muhammadiyah yang diaantaranya: (1) al-Mahdi dan al-Masih; (2) pembaruan (mujaddid); (3) Kematian Nabi Isa as; (4) wahyu; (5) kenabian; (6) kbilafat, (7) jihad. Masuknya Ahmadiyah bermula dari Gerakan Ahmadiyah di Indonesia pada saat awal dimulai dari kajian-kajian pada tahun 1920 oleh Maulana Kwadja Kamluddin, seorang tokoh Ahmadiyah Lahore India lalu mendarat ke Surabaya. Dalam perjalanannya Ahmadiyah sulit mendapat tempat dikalaangan masyarakat Indonesia disebabkan oleh tiga faktor yaitu: (1) kontroversi bidang teologis; (2) kekacaun internal organisasi; (3) salah satu tokoh Ahmadiyah bernama Muhammad Sabitun masuk gerbong PKI.
\end{abstract}

Kata Kunci: Ahmadiyah, Doktrin, Gerakan

\begin{abstract}
Mubammadiyah is a religious organization founded by a reformer named Mirza Gbulam Abmad from India. This idea arose because at that time the condition of Indian society, especially Muslims, experienced backwardness and setbacks in various fields such as religion, politics, economics, social. This movement is ideologicaleschatological aspects, where this movement shows that Mirza Ghulam Ahamad declared bimself al-Mahdi and alMasih who was entrusted by Allah in his dream moral responsibility to advance Islam and for Islam to believe in the Imam al-Mabdi is seen as as a "Islah Judge" or as a "peacemaker". As for the research by Prof. Iskandar Zulkarnain uses a historical approach. From the research results, there are several teachings of Mubammadiyah which include: (1) al-Mabdi and al-Masib; (2) (mujaddid); (3) The death of Prophet Isa as; (4) revelation; (5) prophetic; (6) caliphate; (7) jihad. The entry of Ahmadiyah started with the Ahmadiyy Movement in Indonesia at the beginning of the studies in 1920 by Maulana Kwadja Kamluddin, a prominent Lahore Ahmadiyya in India and then landed in Surabaya. In its journey, Ahmadiyah's position among Indonesian people is difficult because of three factors, namely: (1) controversy in the theological field; (2) internal organizational chaos; (3) one of the Ahmadiyah figures named Muhammad Sabitun entered the PKI carriage.
\end{abstract}

Keywords: Ahmadiyah, Doctrine, Movement 


\section{PENDAHULAN}

Kebangkitan Islam dimulai sejak pertengahan Abad ke-19 dan mulai muncul banyaknya gerakan-gerakan Islam dari berbagai bidang politik, ekonomi, social, dan Agama. Dimana menekankan aspek Islam tertentu, ataupun menekankan kehidupan individual-induvidual maupun masyarakat Islam, sebagai contohnya gerakan Mu’tazilah dan Asy'ariyah. Dilihat dari segi tipologis-nya ada dua macam gerakan dalam Islam yakni gerakan puritanis dan gerakan fundamentalis Islam, contohnya dalam bidang politik, ada gerakan Negara Islam. Dalam bidang ekonomi, ada gerakan antimonopoli, dan gerakan Islam dalam Nasionalisasi. Gerakan dalam Islam dapat pula berupa gerakan pembebasan, seperti yang ada pada gerakan rakyat Afganistan, Aljazair dan Khasmir, gerakan-gerakan ini saling berkesinambungan dan munculnya karena dipengaruhi Islam.

Di India pada saat itu dalam keadaan kacau karena kekalahan kerajaan Mughol dan banyak sekali pemberontakan yang terjadi dari kalangan umat Islam sehingga banyaknya pertumpahan darah dari pemberontakan Mutiny 1857. Dalam kalangan intelektual menginginkan suatu perubahan dan pembaruan dalam Islam adapun yang mencetuskan keinginan dalam pembaruan dalam Islam diawali oleh Sayyid Ahmad Khan dengan mendirikan gerakan Mujahidin., lalu gerakan ini kemudian menjadi dasar utama darul úlum Deoband sebuah perguruan tinggi agama di deoband yang melahirkan ulama-ulama besar India. ${ }^{1}$

Sayyid Ahamd Khan memiliki Ide-ide pembaruan dan dianut oleh para muridnya dan disebarluaskan lalu tumbuhlah apa yang disebut gerakan Aligarh, dan menjadi penggerak utama bagi perwujudan pembaharuan dikalangan umat Islam, dan kemudian diikuti oleh gerakan pembaru dari Amir Ali, Muhammad Iqbal dan Maulana Abdul Kalam Azad. Hal yang melatar belakangi kelahiran Ahmadiyah karena adanya serangan gencar kaum misionaritas Keristen, dan berdirinya Universitas Alighar. Ahmadiyah lahir sebagai protes terhadap keberhasilah kaum misionaritas Keristen memperoleh pengikuit-pengikut baru. Selain itu, juga sebagai protes terhadap paham terhadap rasionalis dan westrenisasi yang dibawa oleh

${ }^{1}$ H. J Benda, Prespektif Islam di Asia Tenggera, terj. Azyumardinazra, Jakarta: Yayasan Obor Indonesia, 1989), hlm.69-70 
sayyid Ahmad Khan dengan Alighar dan Smith, lahirnya Ahmadiyah juga dipengaruhi oleh protes kemerostan umat Islam dalam berbagai bidang. ${ }^{2}$

Seorang pembaru Islam yang bernama Mirza Ghulam Ahmad yang berusaha memperbaiki keadaan umat Islam di India, dikarenakan pada saat itu keadaan masyarakat India khususnya umat Islam di India sangat kacau mudah sekali memulai peperangan yang banyak menumpahkan darah, sikap yang sinkretisan sekeptis. Oleh karena itu Mirza Ghulam Ahmad berusaha memperbaiki dari segi perubahan pola pikir dalam memahami Islam, yakni Rahmatan Lilaalamin, dan mayakini sosok Imam al-Mahdi yang mampu mempersatukan kambali kedamaian.

Ahmadiyah adalah sebuah gerakan keaagamaan dan mencoba menjadi pembaru yang lahir di India pada akhir abad ke-19 yang dipelopori Mirza Ghulam Ahmad. Dengan dilatar belakang oleh kemunduran umat Islam India di berbagai bidang seperti agama, politik, ekonomi, sosial. Hal ini di karenakan perpecahan revolusi di India pada tahun 1857 sehingga mengakibatkan kemenangan oleh pihak Inggris dan menjadikan India sebagai koloni Inggris yang paling terpenting dan menjadi anak Benua Asia. Gerakan ini menekankan aspek-aspek ideologiseskatologis, dimana gerakan ini meyakinkan bahwa Mirza Ghulam Ahamad mendeklarasikan dirinya sebagai al-Mahdi dan al-Masih yang telah diberi amanah dari Allah dalam mimpinya dan ia memiliki tanggung jawab moral untuk memajukan Islam dan bagi umat Islam mempercayai imam al-Mahdi dipandang sebagai "Hakim peng-islah" atau sebagai “Juru Damai". Sebagaimanayang diyakini bahwa al-Mahdi memiliki amanah untuk memepersatukan kembali perpecahan umat Islam, baik dari bidang aqidah ataupun syariee ah dan ciri dari gerakan ini adalah mahdiisme. ${ }^{3}$

Tiga tahun sebelum Mirza Ghulam Ahamd meninggal pada bulan Desember 1905, ia menulis buku atas dasar ilham yang ia terima yang berjudul alWasiyyat, buku itu berisi pemberitahuan bahwa waktu wafat Mirza Ghulam Ahamd

2 Sir Muhammad Iqbal, Islam dan Ahamdiyah, terj. Machnun Husain (Jakarta: PT. Bumi Restu, 1991), hlm, vii.

${ }^{3}$ Ibid., hlm. viii. 
memberikan nasihat kepada Ahmadiyah agar tetap dalam satu, tentram dan selalu bersabar hati. Lalu satu tahun berikutnya didikan sebuah lembaga dengan nama Sadr Anjuman Abmadiyah yang berpusat di Qadian yang berfungsi sebagai pengurus sekolah-sekolah Ahmadiyah dan majalah-majalah yang ditulis atau badan wasiat dan urusanlainnya. Dan perpecahan Ahmadiyah dimulai karena perbedaan keyakinan mengenai Mirza Ghulam Ahamd sebagi Nabi al-Masih dan al-Mahdi, dan golongan yang satunya menganggap ia hanya sebagai Mujaddid. ${ }^{4}$

Munculnya Ahamdiyyah Qadian karena terpilihnya Mirza Basyiruddin Muhmud Ahamd yang menggantikan Mulvi Hakim Nuruddin sebagai Khalifatu al-masih ke II pada tahun 1914. Yang meyakini jika Mirza Ghulam Ahamd adalah Nabi dan ia sudah diramalkan dalam Al- Quran, serta semua orang yang yang tidak di baiát kepada Mirza Bashiruddin Mahmud Ahamd dan sekaligus sebagai pemimpin Ahmadiyah Qadian adalah kafir atau diluar Islam. ${ }^{5}$ Dan golongan Ahmadiyah Lahore yang disebut sengan Ahmadiyah Anjuman Ishaát Isalam, golongan ini dipimpin oleh Maulana Muhammad Ali dan Kwaja Kamaluddin, golongan ini berkeyakinan bahwa pintu kenabian sudah ditutup dan yang terakhir adala Nabi Muhmmada Saw, dan Mirza Ghulam Ahmad hanyalah Mujaddid. ${ }^{6}$

Ahmadiayah memiliki dua aliran dan keduanya telah masuk di Indonesia pada tahun 1924 yang diawali oleh aliran Lahore Gerakan Ahmadiyah Indonesia (GAI) dan di tahun berikutnya 1925 menyusul aliran Qadian Jamaat Ahmadiyah Indonesia (JAI). Dalam perkembagannya Ahmadiyah tentu saja memiliki wadah untuk mendakwahkan ide-ide nya, yang dimulai dari tahapan perintisan, terbentuk sebuah organisasi, lalu tahapan kegiatan dan barulah kemudian berkambang dan bertumbuh. Dalam perkembangannya tentulah tidak mudah bagi Ahmadiyah untuk mengemukakan ide-idenya dan pada awal periode Ahmadiyah masih sangat terbatas daerah penyebarannya. Di Sumatera, misalnya hanya di beberapa kota, seperti Tapaktuan (Aceh), Padang, Bukit tinggi (Sumatra Barat), Palembang. Dan di Jawa pun hanya sedikit kota yang mampu di sentuh seperti Bandung, Surakarta,

${ }^{4}$ Daliar Noer, Gerakan Moderen Islam di Indonesia. 1900-1942 (Jakarta; LP3ES, 1982). $h \operatorname{lm} 71$

${ }^{5}$ Mirza Basyir Ahmad, Silsilah Abmadiyah, terj. Abdul Wahid H.A. (Kemenag: tp., 1997), ${ }^{6}$ Ibid., hlm. 80. 
Jakarta.

Dimana pada saat itu indonesia telah memiliki Gerakan Keagamaan yang didirikan oleh K.H. Ahmad Dahlan yakni Muhammadiah. Sebuah organisasi keagamaan yang dapat digolongkan dalam aliran pemikiran dan gerakan. Ahmadiyah masuk pertama kali di Indonesia mulai abad ke-20. Muhammadiah merupakan gerakan reformasi Islam terkuat yang ada dikalangan Islam Asia Tenggara bahkan mungkin di Seluruh dunia. Masih sedikit sekali penelitianpenelitian tentang Gerakan Ahamadiah di Indonesia dikarenakan minimnya datadata kepustakaan tentang gerakan Ahmadiyah, adapun salah satu Ilmuan yang meneliti gerakan Ahmadiyah di Indonesia ialah Prof. Dr. Iskandar Zulkarnai. Pokok pembahasan yang beliau jadikan perhatiaan dalam kajiannya ialah 1). Kegagalan Ahmadiyah atau permasalahan Ahmadiyah yang tidak mampu bekembang dengan baik seperti Muhammadiah dan Nahdatul Ulama khusunya pada tahun 1920-1942, 2). Pengaruh kegagalan gerakan Ahmadiyah di Indonesia, dan 3). Kontribusi apa yang Ahmadiyah berikan untuk Indonesia.

Salah satu tujuan penelitian Prof. Dr. Iskandar Zulkarnai dalam bukunya yang berjudul "Gerakan Ahmadiyah Di Indoneisa" ialah ingin mengungkapkan fakta sejarah Ahmadiyah sebagaigerakan keagamaan di Indonesia pada masa abad ke-20 khususnya pada akhir pemertintahan Kolonial Belanda. Dan disamping itu beliau juga ingin mengungkapkan atau mengetahui mengapa gerakan Ahmadiyah di Indonesia tidak mampu berkembang dengan baik, dan kontribusi apa saja yang Ahmadiyah berikan kepda Indonesia dalam gerakan modern Islam di Indonesia pada abad ke-20. Berdasarkan penelitian dan pengamatan yang telah didapatkan, Prof. Dr. Iskandar Zulkarnain memiliki sikap kritis terhadap pandangannya tentang Ahmadiyah dari segi Teologis dalam penelitiannya yang dituangkan dalam bukunya yang berjudul "Gerakan Ahmadiyah Di Indonesia". Diantara pemikiran Prof. Dr. Iskandar Zulkarnain yang paling menonjol dalam penelitian Ahmadiyah adalah langkah-langkah yang ditawarkan dalam penelitian ini yaitu aliran Ahmadiah Qadian dan Ahmadiyah Lahore. Sikap kritisnya sebagai penyumbang pemikiran dalam penelitian gerakan Ahmadiyah di Indonesia maka penulis merasa tertarik 
untuk mengkaji buku yang ditulis oleh Prof. Dr. Iskandar Zulkarnain.

\section{METODE PENELITIAN}

Kaitannya dalam metodologi penelitian Prof. Dr. Iskandar Zulkarnain juga menganalisa dan memahami gerakan Ahmadiyah Di Indonesia dengan pendekatan sejarah. Dalam bukunya yang berjudul Penelitian Gerakan Ahmadiyah Di Indonesia. Prof. Dr. Iskandar Zulkarnain menyajikan Metodelogi Heuristik, Kritik Sejarah, Interpretensi dan Penyajian sintesis bentuk kisah sejarah, beliau juga berusaha untuk mejelaskan gerakan Ahmadiyah dari segi Teologis dan kedalam alirannya yakni Ahmdiah Qadian dan Ahmadiyah Lahore. Dengan pendekatan ini, maka hasil yang diinginkan untuk mencapai sebuh tulisan sejarah kritis, mampu menelusuri latar belakang, hubungan yang terkait, kecendrungan yang disampaikan, serta perkembangan Ahmadiyah sebagai organisasi sosial keagamaan yang menekankan dibidang pendakwahan, hal ini diperlukan untuk konsep ilmu pengetahuan sosial dan keagamaan diperlukan untuk mengungkap berbagai peristiwa dari masa lampau agar lebih bermakna dan menjadi kajian suatu penelirtian di kalangan akademis.

\section{PEMBAHASAN}

\section{Doktrin-Doktrin Ahmadiyah}

Sebagaimana yang telah disinggungkan di atas, bahwa penulis dalam memotret buku yang ditulis oleh Prof. Iskandar Zulkarnain lebih fokus untuk melihat doktrin serta gerakannya Ahmadiyah di Indonesia. Berikut beberapa doktrin Ahmadiyah yang sekaligus menjadi banyak perdebatan di Indoensia.

\section{al-Mahdi dan al-Masih}

Masalah al-Mahdi dan al-Masih adalah ajaran pokok Ahmadiyah dikalangan Lahore maupun Qadian, menurut Ahmadiyah doktrin tentang al-Mahdi tidak dapat dipisahkan dengan kedatangan al-Masih diakhir zaman. Hal ini dikarenakan Ahmadiyah khususnya Ahmadiyah Qadian menganggap al-Mahdi dan al-Masih adalah satu tokoh, satu pribadi dimana kedatangannya telah dijanjikan Allah. Dan memiliki tugas untuk membunuh Dajjal dan mematahkan tiang salib, dengan tujuan memberikan kebenaran-kebenaran argumen Islam kepada agama Nasrani dengan 
Titian Ayu N. dan Muhammad Yuslih, Potret Gerakan Ahmadiyah di Indonesia...

dalil-dalil dan bukti-bukti tentang Ibnu Maryam Isa al-Masih, dan tugas kedua ialah untuk mengembalikan kembali syarie at Nabi Muhammad Saw setelah umatnya mengalami kemunduran dalam kehidupan beragama. Adapun dasar yang digunakan mengenai kedatangan al-Masih dan al-Mahdi sesuai dengan sabda Nabi Saw yang diriwayatkan oleh Imam Bukhari yang berarti "Dari Abu Hurairah r.a., ia berkata, Rasullah Saw., bersabda: "Bagaimanakah (sikap) kamu sekalian apabila Ibnu Maryam datang (bersamamu) sedangkan iamammu berasal dari kalanganmu." 7

Dari hadits diatas Ahmadiyah menggagap kata-kata Imammu berasal dari kalanganmu/Imamakum minkum menunjukkan seseorang diantara umat Islam sendiri, yang artinya bukan dari luar umat Islam. Menurut Ahamadiah al-Masih yang akan datang diakhir zaman bukan lah Nabi Isa a.s. yang telah wafat, akan tetapi sesorang muslim yang mempunyai perangai atau sifat-sifat seperti Nabi Isa a.s. dalam pandangan Ahamadiah al-Masih yang dijanjikan itu ialah Mirza Ghulam Ahmad dari Qadian. ${ }^{8}$

Mengenai Nuzul al-Masih (turunnya al-Masih) dalam pandangan umat Islam, baik dari Syieah maupun Sunni, yang akan datang pada akhir zaman untuk mempersatukan umat Islam kembali dan membunuh Dajjal ialah Ibnu Maryam a.s. yang diutus dari Bani Israil yang sekarang dianggap masih hidup di langit dan akhir zaman nanti akan turun kedunia untuk menjalankan misi yang ditugaskan Allah dan dibantu oleh Imam Mahdi. Jadi menurut umat Islam al-Masih dan al-Mahdi itu adalah sosok orang yang berbeda.

Golongan Ahmadiyah sepertinya dalam memahami hadits-hadits tentang turunnya al-Masih secara kiasan atau perumpamaan. Karena mereka berpendapat bahwa al-Masih (Nabi Isa) Ibnu Maryam yang diutus kepada Bani Israil telah wafat secara wajar layaknya manusia biasa dan pada usia lanjut. Orang-orang yang wafat tidak akan bangkit kembali sebelum hari kebangkitan datang, dan dasar yang dipakai terdapat dalam al-Quran surat al-Mukminun ayat 16 dan 100.9

7 Al-Bukhori, Shabih al-Bukhori, juz III, bab turunnya Isa bin Maryam, (Beirut: Alam, alKutub,tt), hlm. 325

8 Mirza Basyiruddin Mahmud Ahmad, Invitation to Ahmadiyah, (Londodn,Boston and Hanly ltd), hlm 30-31.

9 Iskandar Zulkarnain, Gerakan Abmadiyah Di Indonesia, (Yogyakarta, LKiS 
Namun ternyata ada perbedaan dari pemahaman tentang al-Masih dan alMahdi oleh Ahmadiyah Lahore. Ahmadiyah Lahore berpendapat bahwa Nabi Isa benar-benar akan dibangkitkan kembali maka hal ini akan membongkar segel penutup kenabian. Dan hal ini merusak dasar Aqidah Islamiah bahwa Nabi Muhammad adalah penutup para Nabi. Namun jika kedatangan Nabi Isa kelak sebagai umat maka ini akan menurunkan derajat Nabi Isa a.s. dari derajat kenabiam menjadi umat biasa. Kalangan Ahmadiyah juga menggunakan dasar al-Quran surat an-Nisa ayat 157-158, Ahmadiyah menjadikan ayat tersebut sebagai dasar doktrin dan dalam ayat tersebut ada kata "mashalabuhu" dipahami sebagai pembenaran dinaikanya Nabi Isa a.s. keatas tiang salib, akan tetapi menyangkal dengan tegas kematian Isa diatas salib. Jadi menurut Ahmadiyah Nabi Isa al-masih tidaklah sampai mati diatas kayu salib dan meninggal secara wajar sampai usia lanjut, adapun ayat al-Quran yang dijadikan dasar dari argument mereka ialah Quran Surat alMa ${ }^{e e} i d a h$ ayat 117.

Dari ayat tersebut menurut Ahmadiyah menjadi bukti bahwa Nabi Isa a.s. meninggal secara wajar dan menegaskan bahwa beliau berada ditengah-tengah umatnya, dan ia menjadi saksi atas keadaan ditengah-tengah umatnya dan tidak mendapati mereka menganggap Nabi Isa a.s. sebgai Tuhan seperti dokterin agama Kristen yang menuhankan Isa a.s. setelah beliau meninggal.

\section{Masalah Mujaddid (Pembaruan)}

Dokterin tentang Mujaddid dikalangan Ahmadiyah juga menjadi salah satu ajaran pokoknya. Dan dokterin ini juga sangat bertentangan dengan pandangan mayoritas umat Islam. Menurut Ahmadiyah istilah pembaruan yang biasa disebut tajdid juga memiliki pengertian mengembalikan Islam kepada kebenaran Islam yang murni dengan cara melenyapkan kesesatan-kesesatan dan kesalahan yang menyerbu umat Islam dengan cara menghidupkan Iman umat Islam yang sudah surut dan membuat booster baru tentang pandangan kebenaran Islam yang sesuai tuntutan Zaman. Ahmadiyah mendasari dokterin mereka dalam masalah Mujaddid dengan

Yogyakarta,2005), hlm, 86. 
Titian Ayu N. dan Muhammad Yuslih, Potret Gerakan Ahmadiyah di Indonesia...

firman Allah dalam Quran Surat an-Nur ayat 55.10

Ahmadiyah Lahore memandang ayat tersebut bukan saja meramal akan berdirinya kerajaan Islam yang harus dibangkitkan kembali ke-khalifahan yang mampu menggantikan Nabi Muhammad Saw, dan menjadikan kaum muslimin-lah sebagi umat yang memerintah dibumi ini dan sebagai pengganti bangsa Israil dalam hal penjagaan Tanah Suci yang dijanjikan. Dan menurut Ahmadiyah Lahore nabi telah menyebutkan penguasa (Khalifah) yang akan menegakkan agama dan menjadikan umat Islam aman sentosa dan selalu dekat dengan Allah sebagai "orang yang memperbarui agama" yang akan datang tiap-tiap permulaan abad.

Adapun tugas-tugas para Mujaddid adalah menghilangkan konsepsi-konsepsi asing dan kotor yang masuk ke dalam agama Islam lalu menunjukan atau menuntun kembali Islam yang asli dan murni. Adapun tugas para Mujaddid ditentukan oleh kebutuhan dan keadaan pada waktu mereka dibangkitkan. Ada dua aspek pokok sebagai ciri-ciri Mujaddid, pertama uncul pada awal atau permulaan Abad dan kedua, ia mengumumkan bahwa dirinya diangkat oleh Allah sebagai Mujaddid. S. Ali Yasir, tokoh Ahmadiyah Lahore cabang Yogyakarta menambahkan ciri Mujaddid yang ketiga ialah ia yang mampu mengadakan tajdid (pembaruan) dalam Islam. Maka dapat disimpulkan Mujaddid ialah yang diperintahkan oleh Tuhan dan pembaruan yang dilakukan oleh Mujaddid harus sesuai perintah Allah bukanlah inisiatif dirinya sendiri.

Ahmadiyah Lahore mempercayai bahwa Mirza Ghulam Ahmad ialah sebagai pendiri Ahmadiyah, selain sebagai al-Masih dan al-Mahdi ia juga sebagai Mujaddid. Yag diangkat oleh Allah sendiri bukan diangkat oleh manusia. Nama Ahmadiyah diambil dari nama Nabi Muhammad Saw, dimana ketika Mirza Ghulam Ahmad dibangkitkan dalam suasana yang sama pada saat zaman Makkah. Pada saat itu umat Islam dalam keadaan lemah dalam menghadapi musuh Islam yang sangat Kuat. ${ }^{11}$

10 Maulana Muhammad Ali, The Religion of Islam, (T,K.. National Publication \& Printing House, t.t), hlm. 263

11 S. Ali Yasir, Pengantar Pembaharudalam Islam, (Yogyakarta: P.P Yayasan Perguruan Islam Republik Insonesia (PIRI), 1981), hlm, 43. 


\section{Masalah Kematian Nabi Isa a.s.}

Mirza Ghulam Ahmad sebagai pendiri Ahmadiyah beranggapan bahwa Nabi Isa a.s. sebagai manusia biasa dan meninggal sejatinya manusia secara wajar dan tidak meninggal dalam penyalipan yang menjadi kepercayaan dikalangan umat keristiani. Menurutnya Nabi Isa a.s. meninggal pada usia lanjut dan dikubur di Srinagar, Kasymir. Mirza Gulam Ahmad mendasari doktrinnya ini dengan firman Allah dalam Quran Surat al-Maidah ayat 117, Ali Imran ayat 143 dan 54, dan ashShaff ayat 6, dan dengan dasar itu pula yang menjadikan Mirza Ghulam Ahamd adalah al-Masih dan al-Mahdi yang dijanjikan Allah. ${ }^{12}$

\section{Masalah Wahyu}

Ahmadiyah menanggap wahyu tidaklah terhenti hanya sampai pada Nabi Muhammad Saw, namun setelah Nabi Muhammad Saw, pun masih Tuhan masih akan tetap menurunkan wahyu dan bahkan sampai hari akhir. Wahyu Allah tidak hanya diturunkan kepada para nabi dan utusan Allah saja akan tetapi di ilhamkan juga kepada semua umat manusia dan bahkan kepada semua ciptaan-Nya. Menurut Maulan Muhammad Ali, Presiden Ahmadiyah Lahore, sebagaimana yang terdapat dalam tafsir Al-Quran yang ia susun, kata wahyu biasa diterjemahkan sebagai diilhamkan, yang masuk dalam kalbu nabi dan orang-orang tulus. Adapun ringkasan dalam al-Quran yang ditafsirkan oleh Maulan Muhammad Ali ada lima macam wahyu Allah. ${ }^{13}$

1. Wahyu Allah yang diturunkan kepada makhluk yang tak bernyawa, seperti bumi dan langit (QA Fussilat ayat 11-12)

2. Wahyu Allah yang diturunkan kepada binatang-binatang, seperti lebah (QS An-Nahl ayat 68-69)

3. Wahyu Allah yang diturunkan kepada Malaikat (QS Al-Anfal ayat 12)

4. Wahyu Allah yang diturunkan kepada manusia biasa (bukan Nabi) seperti para sahabat Nabi Isa (QS Al-Ma ${ }^{e e} i d a h$ ayat 11) dan ibn Nabi Musa (QS Al-Qasas ayat 7), dan

12 Iskandar Zulkarnain, Gerakan Abmadiyah Di Indonesia., hlm, 101.

13 Ibid. 
5. Wahyu Allah yang diturunkan kepada para Nabi dan Rasul (QA AlAnbiya ayat 7 dan An-Nisa ayat 164). ${ }^{14}$

Dari kelima macam wahyu diatas bentuknya tidaklah sama sebagai contoh, wahyu yang diberikan kepada lebah berupa naluri (instinct), sedangkan wahyu yang diberikan kepada para nabi firman yang menyatakan kehendak Allah untuk memimpin manusia. Ahmadiyah juga menjelaskan bahwa manusia menjalin komunikasi kepada Tuhan yang dikemukakan dalam Al-Quran surat asy-Syura ayat 51, dari ayat tersebut maka ada tiga cara Allah berkomunikasi atau berfirman kepada manusia:

1. Dengan wahyu, wahyu adalah sabda yang diilhamkan yang mampu masuk kedalam kalbu para nabi dan orang-orang tulus. Sabda ini semacam isyarat yang cepat dan langsung diilhamkan dalam hatinya.

2. Dari belakang tirai. Adapun jenis wahyu ini dibagi menjadi tiga macam yaitu. Muhasyarah yang berarti mimpi baik berupa petunjuk Ilahi, dalam keadaan tertidur seperti mimpi. Misalnya Isra’ Mi'raj Nabi Muhammad Saw. (QS AlIsyra $^{\text {ee }}$ ayat 50), Kasyaf yaitu petunjuk Ilahi yang diterima sesorang dalam keadaan sadar, melihat dengan mata rohani. Misalnya Siti Maryam melihat Malaikat Jibril persis seperti seorang lelaki. (QS Ali Imran ayat 41-44) dan, Ilham yaitu petunjuk Ilahi yang diterima dalam keadaan sadar, mendengar dengan telinga rohani. Misalnya firman Allah kepada ibu Nabi Musa (QS alQashash ayat 7).

3. Dengan mengutus malaikat Jibril dalam bentuk kata-kata yang terang. Dan dengan cara inilah semua kitab suci diwahyukan kepada para Nabi. ${ }^{15}$

\section{Masalah Kenabian}

Ahmadiyah membagi masalah kenabian dengan dua pendapat, yang pertama Ahmadiyah Lahore berpendapat dan meyakinin bahwa Nabi Muhammad Saw adalah nabi trakhir. Setelah kematian Nabi Muhammad saw maka tidak ada lagi nabi baru ataupun nabi lama. Lalu bagaimana Mirza Ghulam Ahamd dalam

14 Ibid., hlm. 114.

15 Ibid., hlm. 115. 
Ahmadiyah Lahore? Mirza Ghulam Ahmad bukanlah seorang Nabi, Ia adalah seorang Mujaddid abad ke-14 H. Ahmadiyah Lahore membagi klasifikasi masalah kenabian menjadi dua. Pertama, Nabi Haqiqi, yaitu nabi yang membawa syari'at. Kedua, Nabi Lughawi, yang disebut nabi yang tidak Haqiqi. Ia hanyalah seorang manusia biasa, namun memiliki persamaan yang cukup besar dengan para nabi dan wahyu yang diterima pun tidak bersifat tasyri'i. Terkait nabi Lughawi menurut Syafi R Batuah, tokoh Ahmadiyah Qadian lebih suka menggunakan istilah nabi zhilli atau buruzi yang berarti nabi bayangan.

Sementara Ahmadiyan Qadian, setelah kematian Rasullah masih tetap akan muncul nabi-nabi lain sampai hari akhir. Nabi-nabi yang muncul setelah Nabi Muhammad ialah nabi buruzi, yaitu nabi yang tidak membawa syari'at, lalu mereka menganggap Mirza Ghulam Ahmad adalah seorang Nabi. Ahmadiyah Qadian membagi tiga klasifikasi masalah kenabian:

1. Nabi Shahib asy-Syari'ah dan Mustaqil. Shahib asy-Syari'ah ialah nabi pembawa sayari'at (hukum-hukum) untuk manusia. Mustaqil Ialah hamba Allah yang menjadi nabi dan tidak mengikuti nabi sebelumnya, seperti Nabi Musa a.s., beliau menjadi bukan atas dasar mengikuti nabi atau syari'at sebelumnya namun beliau langsung menjadi nabi dan membawa Taurat. Begitu pula Nabi Muhammad Saw. Nabi Shahib asy-Syari'ah dan Mustaqil.

2. Nabi Mustaqil ghair at-Tasyri’i, hamba Allah yang menjadi nabi dan tidak mengikuti nabi sebelumnya, hanya saja ia tidak membawa syari'at baru. Dalam artian ia hanya ditugaskan oleh Allah untuk menjalankan syarie at yang dibawa nabi sebelumnya, para nabi yang termasuk golongan Mustaqil ghair at-Tasyri’i ialah Nabi Harun, Daud, Sulaiman, Zakaria, Yahya, dan Nabi Isa a.s.

3. Nabi Zhilli Ghair at-Tasyri'i, ialah hamba Allah yang mendapatkan anugarah dari Allah menjadi seorang nabi semata-mata karena kepatuhan-nya kepada nabi sebelumnya juga karena mengikuti syari’atnya. Hamba Allah yang termasuk dalam golongan Mustaqil ghair at-Tasyri’i ialah Mirza Ghulam 
Ahmad. ${ }^{16}$

Status kenabian Mirza Ghulam Ahmad dimata pengikutnya terdapat perbedaan pendapat yang mendasar, yakni versi Lahore dan versi Qadian. Golongan Lahore memandangnya sebagai nabi lughawi atau majazi dalam arti ia bukanlan seorang nabi, namun memiliki kesamaan cukup besar dengan para nabi, yakni ia menerima wahyu. Dan Lahore secara tegas menolak pandangan Qadian yang mengangapnya sebagi seorang nabi setelah Nabi Muhammad Saw, Mirza Ghulam Ahmad hanyalah seorang Mujaddid, karena hal ini merusak Aqidah Islamiyah tentang khatamul ambiya. ${ }^{17}$

\section{Masalah Khilafat}

Ahmadiyah Lahore dan Qadian memiliki perbedaan pendapat juga dalam masalah Khilafat. Dalam pandangan Ahmadiyah Lahore bahwa setelah al-Khulafa' ar-Rasyidun sudah tidak akan ada lagi Khilafah, namun yang ada hanyalah Mujaddid. Sementara pendapat Ahmadiyah Qadian terkait keyakinan mereka tentang Mirza ghulam Ahmad adalah seorang nabi, maka semua nabi adalah seorang Khilafah Allah termasuk juga Mirza Ghulam Ahmad, khalifah yang muncul setalah meninggalnya Mirza Ghulam Ahmad disebut dengan Khalifatul Masih. ${ }^{18}$

Pemahaman Ahmadiyah dalam masalah Khalifah didasari pada Ayat al-Quran. Walaupun dalam penafsirannya mereka berbeda penafsiran, menurut Mirza Basyiruddin Mahmud Ahmad (Aliran Qadian) kata Khalifah di dalam al-Quran digunakan dalam tiga pengertian:

1. Khalifah yang digunakan untuk nabi-nabi yang seakan-akan menjadi pengganti Allah di dunia, misalnya Nabi Adam disebut Khalifah (QS. AlBaqarah 31-32)

2. Khalifah yang digunakan untuk kaum dikemudian hari sebagai pengganti nabi, lalu dipilih oleh kaumnya atau umat sendiri. Sebagai contoh Khalifah Abu Bakar yang menggantikan Nabi Muhammad Saw.

${ }^{16}$ Ibid., 103.

${ }_{17}$ Ahmad, Tjaliyat-Ilabiyat, (Qadian: Mathba Dhia'ul Islam,1906), hlm. 20.

${ }^{18}$ Iskandar Zulkarnain, Gerakan Abmadiyah Di Indonesia., hlm, 119. 
3. Khalifah yang digunakan untuk pengganti nabi karena mereka mengikuti jejak para nabi sebelum mereka. Khalifah-khalifah semacam ini diangkat oleh Allah sebagaimana halnya seorang nabi yang diangkat oleh Allah sendir. Khalifah yang berpangkat seorang nabi ini adalah pembantu atau penerus dakwah setelah nabi sebelumnya atau pada satu masanya. Misalkan Nabi Harun adalah Khalifah bagi Nabi Musa (QS. Al-A“eraf 143). ${ }^{19}$

Dari tiga macam pengertian khalifah diatah bisa disimpulkan sebagai pemimpin-pemimpin rohani. Dari sekian banyak khalifah dan Rasul Allah hanya menyebut beberapa saja dalam Al-Quran yang menjadi pemimpin rohani dan sekaligus pemimpin pemerintahan.

\section{Masalah Jihad}

Ahmadiyah dilatar belakangi keinginan hidup berdamai tanpa perang dan pertumpahan darah. Maka jihad yang diartikan bukanlah jihad untuk selalu berperang, melainkan penyebaran ajaran Islam atau Dakwan Islamiyah dengan pena dan lisan (Jihad kabir) dan memerangi atau menahan hawa nafsu (jihad akbar). Terkait dalam pemerintahan, Ahmadiyah berpendapat bahwa umat Islam harus tetap setia dan taat meskipun dipimpin pemerintah penjajah. Dalam hal ini Ahmadiyah tentang pembaruan yang dilakukan oleh Mirza Ghulam Ahmad, Lahore dan Qadian tidak ada perbedaan pendapat. Dalam hal ini Maulana Muhammad Ali membagi tiga macam jihad yakni, Akbar, Kabir, dan Sighar. ${ }^{20}$

Adapun Salah satu pendapat yang dikemukana oleh A. Mukti Ali, ada lima factor yang mampu melatarbelakangi timbulnya pembaruan Islam yang di gaungkan oleh gerakan Ahmadiyah di Indonesia. Pertama, ketidak bersihan dan campur aduknya kehidupan Islam di Idonesia. Kedua, ketidak efisienan lembaga-lembaga pendidikan agama. Ketiga, aktivitas misi Katolik dan Zending Protestan. Keempat, Sikap acuh tak acuh merendahkan Islam oleh golongan intelektual. Kelima, keadaan politik, ekonomi, dan sosial sebagai akibat keadaan Indonesia sebagai negeri

19 Malik Ghulam Farid (ed), The Holy Quran, Arabic Text and English Tranlation With Commentary. vol,I Part I, (Oxford:Islam International Publication Ltd, 1988), hlm.77-78

${ }^{20}$ Iskandar Zulkarnain, Gerakan Ahmadiyah Di Indonesia., hlm, 125. 
jajahan. ${ }^{21}$

Sebenaranya informasi kedatangan paham Ahmadiyah di Indonesia tidaklah jelas. Ini dilihat dari latar belakang kemunculannya di Indonesia. Namun bila dilihat dari sudut pandang Historis, kemunculan sebuh gerakan tidak akanlah terlepas dari pelaku, waktu, dan tempat. Hal ini senada dengan Jhon Edwerd Sullivan yang mengutip Karl Jaspers dalam bukunya yang mengatakan bahwa suatu peristiwa akan kejadian sejarah yang menyebabkan kemajuan budaya ditentukan oleh man, time, and place.

\section{Gerakan Ahmadiyah di Indoneseia}

Awal kemunculan Ahmadiyah dimulai dari majalah-majalah dan buku-buku yang terbit diluar negeri dan rasa penasaran dua Intelektual yang mendengar bahwa pengajaran Islam di India tidak kalah hebat dengan pengajaran Islam di Timur. Pada waktu itu, berangkatlah untuk menuntut Ilmu di India kedua tokoh penting yaitu Abu Bakar Ayyub dan Ahmad Nuruddin lalu di susul para siswa lainnya. Lalu Perspektif Federspiel menyatakan bahwa kedatangan Ahmadiyah di Indonesia melalui kedatangan para siswa yang kembali ke Indonesia setelah belajar di sekolah Ahmadiyah di India pada akhir abad ke-19 khususnya pemuda-pemuda Sumatra 1925 sebagai contoh Abdul Sami Suamntri, pada saat itu dan membawa paham Ahmadiyah Qadian. Pada saat para siswa belajar di India mengirim surat sekolah di Ahmadiyah Sechool sangat menyenangkan dan mengirim propagandis-propagandis ke Indonesia. ${ }^{22}$

Sementara informasi dari buku-buku, majalah-majalah dan artikel tentang Ahmadiyah yang terbit diluar negeri di Singapure edisi Melayu (1918). Dan baru diperkenalkan oleh tokoh Ahmadiyah langsung pada tahun 1920 dan baru diketahui orang Indonesi dari tahun 1921-1922.23

Gerakan Ahmadiyah di Indonesia pada saat awal dimulai dari kajian-kajian pada tahun 1920. Maulana Kwadja Kamluddin, seorang tokoh Ahmadiyah Lahore

${ }^{21} \mathrm{Ibid} ., 127$.

${ }^{22}$ John Edward Sullivan, Prophets of The west: An International to the Philoshophy of History, (New York: Halt Rinehart and Winston,Icn., t.t), hlm 32-34.

${ }^{23}$ Van de Mehden, Religion and Nasionalism in Southest Asia,(t.p: The Universty of Wisconsin /press. 1968), hlm. 203. 
India yang membawa misi Islam di Eropa, lalu mendarat ke Surabaya dengan tujuan untuk berobat dan diberi kesempatan untuk menyampaikan pidatonya oleh perimpunan Tashwirul Afkar, dalam peringatan acara mauled Nabi di Masjid Ampel Surabaya. Kajian ini hanya sampai tahun 1942 dan karena terkendala oleh masa penjajahan Jepang pada saat itu maka terhentilah aktivitas kegiatan dakwah, termasuk kajian Ahmadiyah dan mulai kembali baru pada tahun $1947 .{ }^{24}$

Dalam perjalanan berdirinya Ahmadiyah di Indonesia tidaklah mudah dan banyak sekali kendala, mulai dari ejekan dengan kata-kata Dajjal, penghinaan, bahkan penganiyaan. Ahmadiyah tetep dengan misinya berdakwah dengan tulus dan tabligh ke seluruh dunia dengan mengembalikan bendera Islam sejati. Hal ini sangat dirasakan pada awal berdiri khususnya di Padang Bukit Tinggi. Maulana Ali adalah tokoh Qadian yang pertama kali diutus oleh Khalifahtul Masih ke II untuk tabligh atau berdakwah. Perjalananya dalam menyebarkan Ahmadiyah di Indonesia dimulai Kotaraja, Banda Aceh. Akhirnya pada tanggal 2 October 1925 ia tiba di Tapaktuan ia tinggal di rumah Muhammad samin, orang yang pernah belajar di Qadian. ${ }^{25}$ Masyarakat di Tapaktuan ternyata telah mengenal kepercayaan akan kedatangan Imam Mahdi, hal ini dikarenakan para pelajar Ahmadiyah School yang berasal dari Tapaktuan sering berkirim surat agar jika utusan pertama dari Imam Mahdi datang diterima dengan sebaik-baiknya.

Rahmat Ali dalam memulai tablighnya ia memakai pakaian sebagaimana yang dipakai di Qadian sehingga tampak berbeda dan membuat ketertarikan tersendiri. Bahkan dalam waktu yang singkat sudah banyak pengikut secara terang-terangan mengikuti paham Ahmadiyah sebagai contoh Mamak Gemuk, Munir, Ali Sutan Marajo dan masih bayak lagi. Bahkan Mamak Gemuk pun menjadikan rumahnya sebagai tempat perkumpulan Ahmdiyah, dengan demikian Tapaktuan telah berdiri jemae at Ahmadiyah. ${ }^{26}$

Setelah sukses mendirikan jema'at di Tapaktuan Maulan Rahmat Ali pindah dan melanjutkan penyebarannya menuju Padang pada tahun 1926. Setibanya di

24 Iskandar Zulkarnain, Gerakan Ahmadiyah Di Indonesia., hlm, 172.

25 Ibid., hlm, 179.

26 Ibid. 
Titian Ayu N. dan Muhammad Yuslih, Potret Gerakan Ahmadiyah di Indonesia...

Padang ternyata Maulana Rahmat Ali memulai dakwahnya sama ketika di Tapaktuan, namun tenyata di hal ini malah membuat resah warga Padang dan menimbulkan reaksi dan pertentangan. Akhirnya berdirilah "Komite Mencari Hak" dimana saat itu mempertemukan mubaligh Ahmadiyah dengan ulama Minangkabau, namun pada tanggal yang sudah ditentukan ternyata ulama Minangkabau tidak menghadirinya kecuali murid-muridnya.

Adapun reaksi lain dan pada tahun yang sama datang dari ayah Hamka, Dr. H. Abdul Karim Amrullah, yang mengecam keras paham Ahmadiyah yang dibawa Maulana Rahmat Ali dan menganggap Ahmadiyah berada diluar Islam, dan lebih tegasnya lagi "Kafir". Ahmadiyah di Padang pada awal berdirinya hanya berjumlah 15 orang dan sasaran penyebaran Ahmadiyah dimulai dengan golongan muda yang masih berambisius dan mengharapkan ke Moderisasian, hal ini dikarenakan Ahmadiyah ketika menyampaikan pidato-pidatonya menggunakan bahasa Arab dan Inggris. Setelah kepulangan Ahmad Nuruddin dan Zaini Dahlan dari Qadian dan menuju kampung halamannya, hal ini mejadikan bertambahnya tenaga mubaligh di Sumatra. Lalu pada tahun 1929 Maulana Rahmat Ali meninggalkan Sumatra dan pergi ke Jawa, namun ia tidak melakukan pendakwahan ke Jogjakarta.

Ahmadiyah Lahore sudah terlebih dahulu dikenal di Jawa, tepatnya di kota Yogyakarta pada tahun 1924. ${ }^{27}$ Setahun lebih awal dari Ahmadiyah Qadian yang dikenal di Sumatra atau dua belas tahun setelah berdirinya Muhammdiyah. Mubaligh yang menyebarkan Ahmadiyah Lahore di Yogyakarta pertama kali ialah Mulana Ahmad dan Mirza Wali Ahmad Baig, penjelasan dari Muhamdiyyah, Wali Ahmad Baig semulanya ingin pergi berdakwah ke Malia, namun terkendala Biaya hidup yang tidak cukup maka terpaksa tinggal di Indonesia. Dan ada pula pendapat lain yang mengatakan bahaw Maulana Ahmad dan Mirza Wali Ahmad Baig bermaksud ke Cina dan hanya berniat berhenti sebentar untuk mengadakan kunjungan singkat ke Indonesia. Namun kedua Mubaligh Ahmadiyah Lahore ini mengubah niat-nya setelah melihat penyiaran agama Keristen di Jawa yang sangat

27 G.F. Pijper, de Ahmadiyah in Indonrsia in Bingkisan Budi, (Leiden: A.W. Sijthoff's Uitgeversmaatschppij N.V, 1950), hlm, 251. 
kuat dan sukses. ${ }^{28}$

Mubaligh Ahmadiyah Lahore ini awal mulanya mendapat bantuan dari organisasi Muhammadiyah, dan Wali Ahmad Baig pun tinggal di rumah Haji Hilal. Seiring berjalannya waktu Ahmadiyah memiliki daya pikat tersendiri dengan berdakwah menggunakan bahasa Inggris dan pada saat itu masih cukup tabu di kalangan umat Islam khususnya Yogyakarta. ${ }^{29} \mathrm{Hal}$ ini adalah salah satu kemajuan awal Ahmadiyah di Indonesia, banyak sekali pemuka dan tokoh-tokoh Muhammadiyah yang tertarik untuk belajar bahasa dan kajian Ahmadiyah. Setelah wafatnya KH. Ahamd Dahlan, maka terjadi kekosongan figure untuk mengadukan segala macam masalah dan siraman keilmuan. Lalu untuk mengisi kekosongan figure Wali Ahmad Baig lah yang menggantikan. Berkaitan dengan kegiatan dan pengajaran bahasa Inggris yang diberikan Wali Ahmad Baig ternyata diarahkan untuk memahami The Holy Qur'an dengan terjemahannya.

Kedekatan Muhammadiyah dan Ahmadiyah menjadi lebih tampak setelah pemuda Muhammdaiyah diutus belajar ke Lahore untuk dilatih sebagai mubaligh Ahmadiyah mereka adalah Kiai Maksoem, Kiai Sabit dari Wonosobo. Dalam masa keemasan Ahmadiyah di Indonesia ternyata ada satu artikel yang membuat Ahmadiyah menjadi kehancuran dan merusak persahabatan dengan Muhammadiyah. Artikel tersebut mengemukakan bahwa di India dan Afganistan terjadi pertentangan keras terhadap gerakan Ahmadiyah tentang doktrin-doktrin yang mereka gunakan. Informasi dalam artikel tersebut menimbulkan prediksi bahwa gerakan Ahmadiyah akan menyebabkan perpecahan di kalangan masyarakat Islam Indonesia.

Akibat pemuatan artikel tersebut, kantor-kantor Pemerintahan Belanda di Jawa tertarik akan kemajuan Ahamdiya. Setelah berkonsultasi dengan Kreamer, seorang misinoritas Kristen, dan Haji Muchtar seorang tokoh Muhammadiyah, memutuskan bahwa tidak akan nada penggabungan antara Ahmadiyah dan Muhammadiyah lagi. Karena Muhammadiyah merasa kecewa terhadap aspek-aspek doktrin gerakan Ahmadiyah dan pada tahun 1926 Muhammadiyah mejaga jarak

${ }^{28}$ Majalah Tempo, 21 September 1974 ,hlm, 45.

${ }^{29}$ Iskandar Zulkarnain, Gerakan Abmadiyah Di Indonesia., hlm, 181. 
dengan Ahmadiyah. Walaupun ada pembelaan dari Ahmadiyah Lahore bahwa mereka tidak menganggap Mirza Ghulam Ahmad sebagi Nabi namun sebagai seorang Mujaddid. Namun karena Ahmadiyah Qadian sudah terlajur tersebar didaerah Sumatra dan membuat Muhammadiyah merasa gagal untuk menghentikan paham gerakan Ahmadiyah.

Ada beberapa faktor penghambat perkembangan Ahmadiyah di Indonesia. Factor pertama karena kontroversi bidang teologis, terutama tentang pandangan mereka terhadap permasalahan kenabisan, wahyu, kematian Nabi Isa a.s., al-Masih dan al-Mahdi yang dipandang Ahmadiyah sebagai doktrin pembaharuan. Namun hal ini ternyata sangat bertolak belakang dalam pandangan mayoritas umat Islam di Indonesia bahkan hal ini mengundang reaksi keras. Doktrin-doktrin teologis Ahmadiyah seperti inilah yang menjadi kontroversial dan menjadi faktor penghambat perkembangan Ahmadiyah di Indonesia. Faktor kedua, datang dari permasalahan kelonggoran organisasi, hal ini terlihat dari terbentuknya kepengurusan Besar Ahmadiyah setelah empat tahun kedatangannya barulah terbentuk sebuah struktur Organisasi dan terjadi beberapa kali perubahan nama Organisasi dan kerancuhan Anggaran Rumah tangga, anggaran dasar serta setatus badan hukum yang mereka tata, secara tidak langsung hal ini menjadi faktor kendala berkembangnya Ahmadiyah di Indonesia.

Faktor ketiga, ketika seorang tokoh Ahmadiyah masuk dalam PKI ialah Muhammad Sabitun. Gerakan Ahmadiyah bukanlah gerakan yang bebaskan politik, dan tidak mencapuri politik apa saja walaupun mereka menyadari pentingnya politik. Namun anggota Ahmadiyah pun diberi kebebasan untuk berpolitik asal politik itu tidak bertentangan dengan asa ketuhanan yang Maha Esa. Ketika anggota Ahmadiyah masuk dalam politik tujuan mereka sebnarnya untuk kepentingan Dakwah. Muhammad Sabitun seorang tokoh Ahmadiyah yang sangat disegani di Wonosobo, keterkaitannya dalam plolitik yakni ia masuk dalam Partai Komunis Islam (PKI). Sebagai seorang tokoh mubaligh, melalui partai tersebut ia ingin mengIslamkan orang-orang Komunis, termasuk warga Cina. Karena dampak seorang tokoh yang disegani masuk PKI, hal ini memiliki dampak yang cukup 
besar. Banyaknya warga Ahmadiyah kemudian ikut menjadi anggota PKI, terutama didaerah Wonosobo. Padahal pada saat itu PKI menjadi salah satu partai terlarang di Indonesia, dengan demikian yang dilakukan Muhammad Sabitun untuk masuk ke PKI merugikan Ahmadiyah.

Kontribusi Ahmadiyah terhadap Modern Islam, terkait pendapat H. J. Benda menyatakan secara Intelektual, reformisme India, dan tokoh-tokoh pembarunya tidak dapat di abaikan dan memiliki dampak pengaruh dalam Modern Islam. Meski pun Dakwah Gerakan Ahmadiyah kurang berhasil, khususnya Ahmadiyah Lahore yang dibawa Mirza Wali Ahmad Baig ke Jawa. Tetapi sebagai suatu sumber Ilham, pemikirannya menjadi panutan bagi beberapa muslim terkemuka Indonesia. Gerakan Ahmadiyah yang lahir dari India sebagai pendukung Ide Libral dan menjadi mempengarui intelektual muda Indonesia.

Tafsir Al-Quran yang mereka tulispun memilik kontribusi dan telah diterjemakhan kedalam 64 bahasa di seluruh Dunia. Beberapa karya tokoh-tokoh Islam Indonesia tidak sedikit mengambil bahan kutipan dari literatue-literatur Ahmadiyah, seperti dalam buku Islam dan Sosialisme H.O.S. TjokroamonIto mengutip dari buku Mulana Muhammad Ali, “Tarikh Agama Islam” mengadopsi dari buku Muhammad Ali, Mohammad The Prophet. Ia juga menerjemahkan The Holy Qur'an. Bahkan Al-Quran yang di terjemahkan Departeman Agama RI juga mengadopsi dari The Holy Qur'an karangan Maulana Muhammad Ali. Mengenai Posisi Ahmadiyah saat ini di Indonesia dalam keputusan dan rekomdasi organisaiorganisai Islam sedunia, menyatakan bahwa Ahmadiyah telah menjadi golongan kafir dan keluar dari Islam karena dokterin-dokterin yang mereka ajarkan telah keluar dari dasar Islam.

\section{KESIMPULAN}

Dari penjelasan di atas dapat kita tarik benang merah bahwa, kemunculan Ahmadiyah berasal dari kegentingan di India pada saat itu dan Mirzagulam Ahmadi berusah untuk memperbarui kemurnian Ajaran Agama Islam dan mejadikan dirinya sebagai juru pendamai al-Masih dan al-Mahdi. Ahmadiyah memiliki dua aliran, yakni Lahore dan Qadian. Keduanya memiliki beberapa perbedaan pendapat dalam 
Doktri-doktrin yang mereka bawa. Gerakan Ahmadiyah Lahore Indonesia berasaskan, pertama Al-Quran sebagai kitab suci terakhir dan sempurna. Kedua, keyakinan bahwa Nabi Muhammad Saw adalah nabi terakhir dan sesudahnya tiada lagi nabi baru. Ketiga, pengakuan bahwa setelah peninggal Nabi Muhammad Saw, akan datang Mujaddid-mujaddid baru dan Mirza Ghulam Ahamad adalah Mujaddid abad ke-14, namun Ahmadiyah Qadian menganggapnya sebagai nabi baru menjadikannya al-Masih dan al-Mahdi.

Tujuan dari Gerakan Ahmadiyah yakni menegakan kedaulatan Tuhan agar umat Indonesia mencapai keadaan jiwa atau kehidupan bain yang disebut salim. Adapun cara untuk mencapai tujuan tersebut ada beberapa cara yang harus dilakukan, yakni menerbitkan dan menyebarkan brosur-brosur, ceramahkunjungan. Surat menyurat dan bai'at untuk mencapai tujuan dalam penyebaran kebenarannya dalam agam Islam, pertama dilakukan dengan lisan, tulisan dan amal. Kedua dengan mendirikan badan-badan sosial. Literature corak keagamaan mereka lebih bercorak Rasional dan perkembangannya di Indonesia tidaklah mulus banyak sekali kendala dan tantangan dari para ulama organisasi keagamaan lain seperti, Muhammadiyah, Nahadul Ulama dan Persatuan Islam dan ternyata masih dapat bertahan pada saat ini walaupun perkembanganya kurang dan dilarang oleh organisasi-organisai Islam Sedunia, menyatakan mereka termasuk dalam golongan Kafir dan keluar dari ajaran Islam.

\section{DAFTAR PUSTAKA}

Alhadar A. H. (1980). Ahmadiyah Telanjang Bulat si Panggung Sejarah . Bandung: al-Maárif.

Ahmad. 1906. Tjaliyat-Ilahiyat. Qadian: Mathba,Dhia'ul Islam.

Al-Bukhori. Shahih al-Bukhori, juz III, bab turunnya Isa bin Maryam. Beirut: Alam, alKutub.

Ahmad B. M. 1997. Silsilah Abmadiyah, terj. Abdul Wahid H.A. Kemenag: tp.

Ahmad M. B. M. Invitation to Ahmadiyah. London: Boston and Hanly, tt.

Ali M. M. The Religion of Islam. T,K.. National Publication\&Printing House, t.t.

Farid (ed) G. M. 1988. The Holy Quran, Arabic Text and English Tranlation With Commentary. vol,I Part I. Oxford: Islam International Publication Ltd.

Benda J.H. 1989. Prespektif Islam di Asia Tenggera, trjh. Azyumardinazra. Jakarta: Yayasan Obor Indonesia.

Iqbal, M. S. 1991. Islam dan Ahamdiyah, terj. Machnun Husain. Jakarta: PT. Bumi 
Restu.

Indonesia, M. (Director). (2019). Sejarah Masuknya Ahmadiyah di Indonesia "masjid ke masjid" Motion Picture.

Indonesia, Y. C. (Director). (2020). Mengenal Ahmadiyah Lebih Dekat (Motion Picture).

Mehden V. D. 1968. Religion and Nasionalism in Southest Asia,(t.kp.: The Universty of Wisconsin / press.

Majalah Tempo, 21 September 1974.

Noer D. 1982. Gerakan Moderen Islam di Indonesia. 1900-1942. Jakarta: LP3ES.

Pijper G. F. 1950. de Abmadiyah in Indonrsia in Bingkisan Budi. Leiden: A.W. Sijthoff's Uitgeversmaatschppij N.V.

Sullivan E. J. Prophets of The west: An International to the Philoshophy of History. New York: Halt Rinehart and Winston, Icn, t.t.

Thaha F. S. (1981). Ahmadiyah Dalam Persoalah. Bandung: al-Maárif.

Yasir A. S. 1981. Pengantar Pembaharun dalam Islam. Yogyakarta: P.P Yayasan Perguruan Islam Republik Insonesia (PIRI).

Zulkarnain, I. 2005. Gerakan Abmadiyah Di Indonesia. Yogyakarta: LKiS Yogyakarta. 